Original Research

\title{
New Electrocatalysts Prepared by Co-Sputter Deposition for the Direct Oxidation of Methanol
}

\author{
Dan Fang ${ }^{\ddagger}$, Sri Narayan *
}

Department of Chemistry, University of Southern California, University Park, Los Angeles, California, USA; E-Mails: danfang@usc.edu; sri.narayan@usc.edu

¥ Current Affiliation: Carbon Capture, 130 W Union St, Pasadena, California, USA; E-Mail: dan@carboncapture.com

* Correspondence: Sri Narayan; E-Mail: sri.narayan@usc.edu

Academic Editor: Maria Helena de Sá

Special Issue: Design and Characterization of New Electrocatalysts for Low Temperature Fuel Cells

Journal of Energy and Power Technology

2021, volume 3 , issue 3

doi:10.21926/jept.2103038
Received: May 25, 2021

Accepted: August 09, 2021

Published: August 13, 2021

\begin{abstract}
Direct methanol oxidation catalysts $\mathrm{Pt}_{1-\mathrm{x}}-\mathrm{Ta}_{\mathrm{x}}(0<\mathrm{x}<1)$ were prepared using co-sputter deposition. Characterization of these thin film catalysts was performed using scanning electron microscopy (SEM), energy dispersive X-ray (EDX), X-ray Diffraction (XRD) and X-ray photoelectron spectroscopy (XPS). Assessment of the methanol oxidation activity of $\mathrm{Pt}_{1-\mathrm{x}}-\mathrm{Ta}_{\mathrm{x}}$ catalysts were achieved through half-cell experiments. Among all the $\mathrm{Pt}_{1-\mathrm{x}}-\mathrm{Ta}_{\mathrm{x}}$ catalysts, $\mathrm{Pt}_{0.77^{-}}$ $\mathrm{Ta}_{0.23}$ catalyst showed the best electrochemical area specific activity which was comparable to platinum-ruthenium alloy on carbon (PtRu/C) catalysts. $\mathrm{Pt}_{1-\mathrm{x}}-\mathrm{Ta}_{\mathrm{x}}$ catalysts worked as bifunctional methanol oxidation catalysts. The surface oxides species activated water molecules and hence facilitated the process of removing carbon monoxide from the platinum sites. The

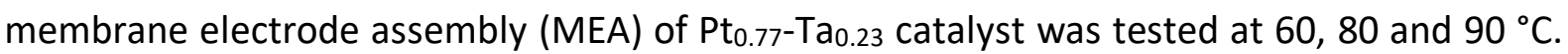
The power density achieved at $90{ }^{\circ} \mathrm{C}$ was $82 \mathrm{~mW} / \mathrm{cm}^{2} / \mathrm{mg} \mathrm{Pt}$, which was 1.82 times of PtRu/C catalyst with similar platinum loading.
\end{abstract}

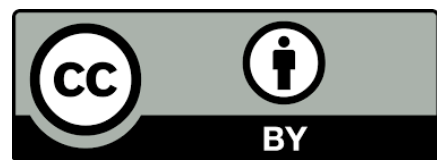

(C) 2021 by the author. This is an open access article distributed under the conditions of the Creative Commons by Attribution License, which permits unrestricted use, distribution, and reproduction in any medium or format, provided the original work is correctly cited. 


\section{Keywords}

Electrocatalyst; methanol fuel cell; sputter deposition

\section{Introduction}

Direct methanol fuel cells (DMFCs) are attractive because of the high energy density of methanol [1], the overall simplicity of the fuel cell system $[2,3]$ and the ease of re-fueling with a liquid fuel. State-of-art DMFC systems use platinum-ruthenium catalysts at the anode, platinum catalysts at the cathode, with a proton-conducting polymer electrolyte membrane separating the two electrodes [4-6]. Thus far, the best commercial anode catalyst is a highly-dispersed platinum-ruthenium alloy (atomic ratio of Pt:Ru of 1:1) supported on high surface area carbon such as Vulcan XC-72. This catalyst is commercially available with $10 \mathrm{wt} . \%$ to $80 \mathrm{wt} . \%$ total metal loading. In this type of catalyst, the roles of platinum and ruthenium are quite distinct and hence it is referred to as a bi-functional catalyst [7]. Platinum dissociates the methanol molecule, while ruthenium dissociates the water molecule. The resulting adsorbed species, $-\mathrm{CO}_{\text {ads }}$ and $-\mathrm{OH}_{\text {ads }}$, react on the surface to form carbon dioxide. The chemical equations below represent the process that occurs on the catalyst [8]:

$$
\begin{gathered}
\text { Methanol Dissociation: } \mathrm{Pt}+\mathrm{CH}_{3} \mathrm{OH} \rightarrow \mathrm{Pt}-\mathrm{H}_{\mathrm{ads}}+\mathrm{Pt}-\mathrm{CO}_{\mathrm{ads}} \\
\text { Water Dissociation: } \mathrm{Ru}+\mathrm{H}_{2} \mathrm{O} \rightarrow \mathrm{Ru}-\mathrm{H}_{\mathrm{ads}}+\mathrm{Ru}-\mathrm{OH}_{\mathrm{ads}} \\
\text { Surface Recombination: } \mathrm{Pt}-\mathrm{CO}_{\mathrm{ads}}+\mathrm{Ru}-\mathrm{OH}_{\mathrm{ads}} \rightarrow \mathrm{Pt}+\mathrm{Ru}+\mathrm{CO}_{2}+\mathrm{H}^{+}+\mathrm{e}^{-}
\end{gathered}
$$

Although this type of nano-particulate Pt-Ru catalyst is thus far the most active for the electrooxidation of methanol [9], a large precious metal loading is required to realize practically relevant current densities. Approximately 60-80 grams of Pt-Ru alloy is required for a $1 \mathrm{~kW}$ fuel cell. Additionally, the ruthenium part of the Pt-Ru catalyst is prone to oxidation and dissolution if certain threshold potentials are exceeded, limiting the durability of the catalyst. The accelerated degradation of ruthenium within six months of operation was observed in a 400-Watt, 80-cell direct methanol fuel cell stack by Valdez et al. $[10,11]$. Thus, due to the high precious metal catalyst loadings and the relatively poor durability of ruthenium-based catalysts, the wide-spread commercialization of the direct methanol fuel cell to sizes larger than $1 \mathrm{~kW}$ has not occurred.

Earlier research has indicated that tantalum and niobium are potential alternatives to ruthenium in methanol oxidation catalysts [12-14]. In these studies, it was shown that oxygen vacancies on the passivation layer of tantalum and niobium oxides activated water and therefore played the role of ruthenium in bi-functional catalysts. A tantalum-modified platinum electrode was studied and the bi-functional mechanism on tantalum-modified platinum was proposed by Masud et al. [13]. In another study, the methanol oxidation activity of Pt-Ta alloy showed improvement over a platinum catalyst [14]. $\mathrm{Ta}_{2} \mathrm{O}_{5}$-encapsulated platinum was prepared and showed improved methanol oxidation performance due to improved surface area [15]. Thus, the use of tantalum to replace ruthenium seemed promising to investigate. To this end, we examined $\mathrm{Pt}_{1-\mathrm{x}}-\mathrm{Ta}_{\mathrm{x}}$ thin film catalysts produced by co-sputtering. The sputter-deposition method is well known for its potential in the synthesis of nanomaterials for electrochemical catalysts $[16,17]$. It allowed us to prepare the catalyst with 
platinum and tantalum in any desired ratio on a various of substrates. We have investigated the structure, morphology and composition of these catalysts by SEM, EDX and XPS. Quasi-steady state voltammetry tests of the catalysts suggested that the $\mathrm{Pt}_{1-\mathrm{x}}-\mathrm{Ta}_{\mathrm{x}}$ catalysts acted through the bifunctional mechanism of methanol oxidation.

In some of the previous literature reports on $\mathrm{Pt}_{1-x} \mathrm{Ta}_{\mathrm{x}}$ catalysts, a combinatorial approach was used with the focus on identifying the most active composition [14]. In our work, we have focused on understanding the effect of composition on the electrochemical parameters and demonstrating the benefits of these catalysts in practical methanol fuel cells. We have also tried to gain insight into the interaction between platinum and tantalum in enhancing the electro-oxidation of methanol that led to optimal catalytic activity, lowered the noble metal content, and enabled the use of these new catalysts in practical cells.

\section{Materials and Methods}

\subsection{Materials Preparation}

\subsubsection{Preparation of Co-sputtered $\mathrm{Pt}_{1-\mathrm{x}}-\mathrm{Ta}_{\mathrm{x}}$ Electrodes}

Co-sputtered $\mathrm{Pt}_{1-\mathrm{x}}-\mathrm{Ta}_{\mathrm{x}}$ electrodes were prepared in a custom-built multi-source sputter deposition system (Explorer Hybrid Coating System, Denton Vacuum). Each $\mathrm{Pt}_{\mathrm{x}}-\mathrm{Ta}_{1-\mathrm{x}}$ electrode was generated by co-depositing platinum and tantalum onto a $2 \mathrm{~cm}$ by $2 \mathrm{~cm}$ carbon fiber composite paper substrate (AvCarb MGL 190). The main chamber was pumped down to $10^{-6}$ Torr before sputtering using a d.c. magnetron source. A five-minute pre-sputtering process was conducted to clean the target surface and remove any possible contamination. Then platinum (from a 2" target of purity 99.95\%, Plasmaterials) and tantalum (from a 2 " target of purity 99.95\%, Plasmaterials) were co-deposited from separate d.c. magnetron sputter sources. The sputter power of the platinum cathode was held at $40 \mathrm{~W}$ while the sputter power of the tantalum cathode was varied between 20 to $140 \mathrm{~W}$ in steps of $20 \mathrm{~W}$. The total catalyst amount was maintained the same while the platinum to tantalum ratio was varied. The background pressure during deposition was maintained at $10 \mathrm{mTorr}$ by an argon flow rate of $35 \mathrm{sccm}$. The substrate holder was rotated at 20 rpm to ensure uniform lateral distribution of the metals in the films. The deposition rates were monitored with a quartz crystal monitor.

\subsubsection{Membrane-Electrode Assemblies Preparation}

The sputtered electrodes prepared in the manner described above were also tested in a full-cell configuration by fabricating membrane-electrode assemblies (MEAs). The MEA consisted of the sputtered electrode with the methanol oxidation catalyst as the anode, Nafion ${ }^{\mathrm{TM}} 117$ as the polymer electrolyte membrane, and platinum black coated on a teflonized carbon fiber paper as the cathode.

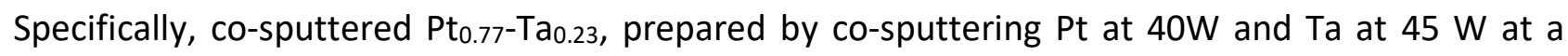
background pressure of 30 mTorr, was selected for the full-cell experiments. The catalyst was sputtered onto a $5 \mathrm{~cm}$ by $5 \mathrm{~cm}$ carbon fiber composite paper (AvCarb MGL 190) coated with multiwalled carbon nanotubes (CNTs) in order to achieve a high electrode surface area for a certain geometric area of the carbon paper. The CNT was dispersed in water and spray coated on the carbon paper to achieve a loading of $0.01 \mathrm{mg} / \mathrm{cm}^{2}$. The total catalyst loading of the anode was $0.15 \mathrm{mg} / \mathrm{cm}^{2}$. 
The platinum loading was $0.04 \mathrm{mg} / \mathrm{cm}^{2}$. A thin coating of Nafion solution (Liquion $5 \%$ Nafion ionomer solution from lon Power) was sprayed over the $\mathrm{Pt}_{0.77}-\mathrm{Ta}_{0.23}$ anode electrode to ensure a continuous proton-conducting path at the interface of the catalyst materials and Nafion membrane in the MEA. We used a hydrophobic substrate for the oxygen electrode and a hydrophilic (water wettable) substrate for the methanol oxidation electrode. Toray TGPH-060 was available readily with $20 \%$ Teflon and hence was used for the oxygen electrode. No comparable Toray product without Teflon was available. Consequently, for a Teflon-free substrate, the AvCarb MGL 190 material was used. Please note that besides their Teflon content, the two substrates were comparable in their properties (See supplementary material Figure S1 and Table S1).

A standard MEA was also fabricated with an anode consisting of commercial Pt-Ru/C catalyst coated on AvCarb MGL 190 carbon paper using catalyst inks prepared with Nafion solution (Liquion $5 \%$ Nafion), isopropanol and water. The mass ratio of PtRu catalyst to the Nafion solution was 1:5. The loading of platinum was $0.04 \mathrm{mg} / \mathrm{cm}^{2}$, which was the same as the anode of the co-sputtered

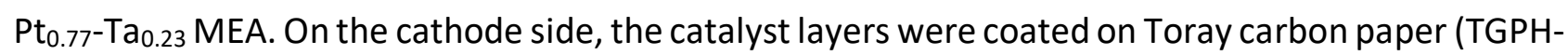
060, 20\% teflonized) using inks containing platinum black and water. The platinum black loading of $2 \mathrm{mg} / \mathrm{cm}^{2}$ on the cathode was maintained in all the full cell studies. The MEA was formed by hotpressing the electrode-membrane sandwich at $140^{\circ} \mathrm{C}$ under a load of about $440 \mathrm{~kg}$ for 15 minutes.

\subsection{Materials Characterization}

\subsubsection{Physical Characterization}

A JEOL JSM 7001 SEM was used to study the morphology of the sputtered catalysts. The metallic compositions of the catalysts were determined by EDX analysis using a Kevex Quantum Detector with an IXRF digital pulse processing analyzer microscope operated at $10 \mathrm{kV}$. The surface composition of the catalysts were investigated using XPS with a magnesium X-ray source (1253.6 eV, SPECS XPS at NETL). The XPS data was analyzed using CASA software and all the XPS data was corrected based on the carbon peak at $284.6 \mathrm{eV}$.

\subsubsection{Half-Cell Electrochemical Measurement}

Electrochemical studies at room temperature were carried out in the "half-cell" configuration using a three-electrode cell. A solution of $0.1 \mathrm{M}$ perchloric acid was used as the electrolyte, a mercury/mercury sulfate (MSE) $\left(\mathrm{Hg} \mid \mathrm{Hg}_{2} \mathrm{SO}_{4}, 1 \mathrm{M} \mathrm{H}_{2} \mathrm{SO}_{4}, \mathrm{E}^{\circ}=0.650 \mathrm{~V}\right)$ electrode was used as the reference electrode, and a Pt wire was used as a counter electrode. A $2 \times 2 \mathrm{~cm}^{2}$ Toray paper coated electrode was used as the working electrode. Electrochemical studies were performed with a Potentiostat/Galvanostat/Frequency Response Analyzer (Ametek-PAR-VMC-4). In a typical measurement, the electrode potential was varied and the current response was measured. The solutions of $0.1 \mathrm{M}$ perchloric acid were de-gassed to be free of oxygen by saturation with argon. A $1 \mathrm{M}$ solution of methanol in $0.1 \mathrm{M}$ perchloric acid was used in all the polarization studies. For the surface area studies, a $0.1 \mathrm{M}$ perchloric acid solution free of methanol was used. The cyclic voltammetry scan between $-0.6 \mathrm{~V}$ and $0 \mathrm{~V}$ vs MSE with a $200 \mathrm{mV} / \mathrm{s}$ scan rate yielded current peaks for the electro-sorption and desorption of hydrogen atoms. The charge under the electrodesorption peak for hydrogen atoms was used to calculate the electrochemically active surface area of the electrodes, after correcting for the double layer charging current. A charge density of 210 
microcoulomb $/ \mathrm{cm}^{2}$ corresponding to a monolayer of adsorption of hydrogen atoms on the platinum sites was used in the surface area calculations [18].

\subsubsection{Full-Cell Test}

For the full cell tests, the MEA was assembled in fuel cell test hardware (Electrode area $25 \mathrm{~cm}^{2}$, Electrochem Inc.). Silicone gaskets were used to achieve sealing. The anode was supplied with a $1 \mathrm{M}$ methanol flowing at $1.1 \mathrm{~L} / \mathrm{min}$. The total volume of solution in the reservoir was 2 liters. The cathode was fed with air flowing at $2 \mathrm{~L} / \mathrm{min}$ at a pressure of $1.7 \mathrm{~atm}$. The solution was circulated past the electrodes at $60^{\circ} \mathrm{C}$ for 1 hour before the start of testing. Then, the cells were tested at $60^{\circ} \mathrm{C}, 80^{\circ} \mathrm{C}$ and $90^{\circ} \mathrm{C}$.

\section{Results and Discussion}

\subsection{Physical Characterization of Co-Sputtered Platinum-Tantalum Catalysts}

Platinum-Tantalum films prepared by co-sputter deposition on carbon fiber paper (AvCarbMGL 190) were studied by Scanning Electron Microscopy. The carbon-fiber paper substrate was a random arrangement of microfibers of about 10 microns in diameter (Figure 1a, b). There was no noticeable difference in the surface morphology of the bare carbon fiber paper and that coated with $\mathrm{Pt}_{0.77^{-}}$ $\mathrm{Ta}_{0.23}$ (Figure 1c, d) except for the slightly increased brightness caused by the back-scattering of electrons from the metal-covered surface. An SEM image of co-sputtered $\mathrm{Pt}_{0.77-}-\mathrm{Ta}_{0.23}$ with higher resolution has been included in the supplemental materials (Figure S2). We have also included the SEM images of two of the tantalum-rich co-sputtered $\mathrm{Pt}_{1-\mathrm{x}} \mathrm{Ta}_{\mathrm{x}}$ with different platinum to tantalum ratios in the supplemental materials (Figure S3). The coverage by the $\mathrm{Pt}_{\mathrm{x}} \mathrm{Ta}_{1-\mathrm{x}}$ films was uniform and complete across the substrate. A glass slide that was placed by the side of the carbon fiber paper during co-sputter deposition, and the thickness of the resulting film was measured by profilometry. With the Ta-rich compositions, the image resolution was poor due to low electronic conductivity of the surface films leading to extensive charging of the sample. The elemental composition mapped using EDX (Figure S4) showed that the composition was uniform across the entire surface of the film. The atomic ratio and thickness of all the films of $\mathrm{Pt}_{\mathrm{x}} \mathrm{Ta}_{1-\mathrm{x}}$ prepared by sputter-deposition are shown in Table 1. 


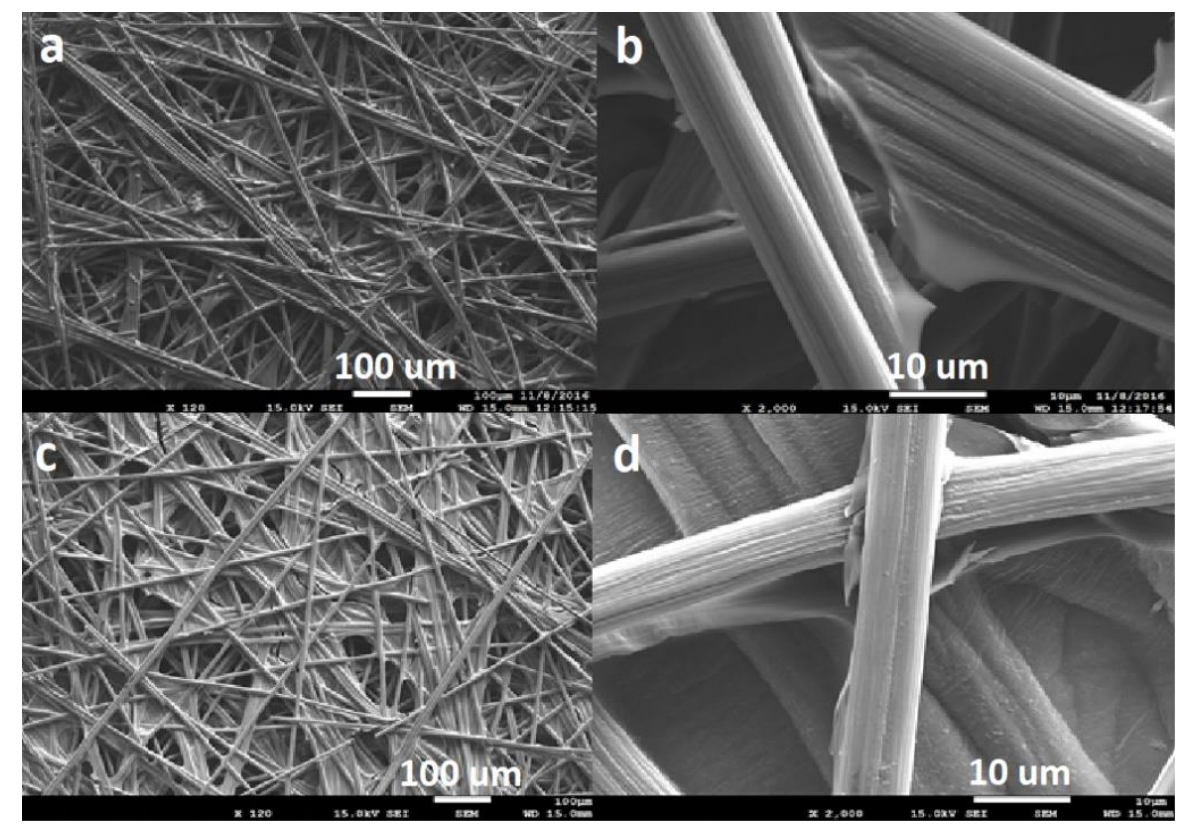

Figure 1 a and b: SEM images of Carbon-Fiber Paper (AvCarb MGL 190), c and d: Carbon-

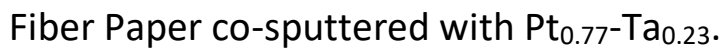

Table 1 Composition and thickness of co-sputtered $\mathrm{Pt}_{1-\mathrm{x}}-\mathrm{Ta}_{\mathrm{x}}$ films.

\begin{tabular}{lllllllll}
\hline Tantalum Sputter Power/Watt & 20 & 40 & 45 & 60 & 80 & 100 & 120 & 140 \\
Platinum Sputter Power/Watt & 40 & 40 & 40 & 40 & 40 & 40 & 40 & 40 \\
Ta:Pt Atomic Ratio & 0.132 & 0.264 & 0.298 & 0.957 & 1.34 & 1.55 & 1.69 & 1.83 \\
Pt:Ta Stoichiometry & $88: 12$ & $79: 21$ & $77: 23$ & $51: 49$ & $43: 57$ & $39: 61$ & $37: 63$ & $35: 65$ \\
$\mathrm{Ta}_{2} \mathrm{O}_{5}$ : Pt Volume Ratio & 0.37 & 0.74 & 0.83 & 1.1 & 1.5 & 1.8 & 2.2 & 2.6 \\
Catalyst Layer Thickness/nm & 6.6 & 13 & 15 & 20 & 26 & 33 & 39 & 46 \\
\hline
\end{tabular}

The XRD patterns of $\mathrm{Pt}_{0.77}-\mathrm{Ta}_{0.23}$ showed the face-centered cubic phase for platinum with prominent reflections from the (100) and (110) crystal faces, and orthorhombic tantalum(V) oxide, $\mathrm{Ta}_{2} \mathrm{O}_{5}$ (Figure 2). Absence of shift in the platinum peaks suggested that no solid solution was formed. The average crystallite size of platinum and tantalum oxide estimated using the Scherrer equation [19] to be $7.2 \mathrm{~nm}$ and $3.2 \mathrm{~nm}$, respectively.

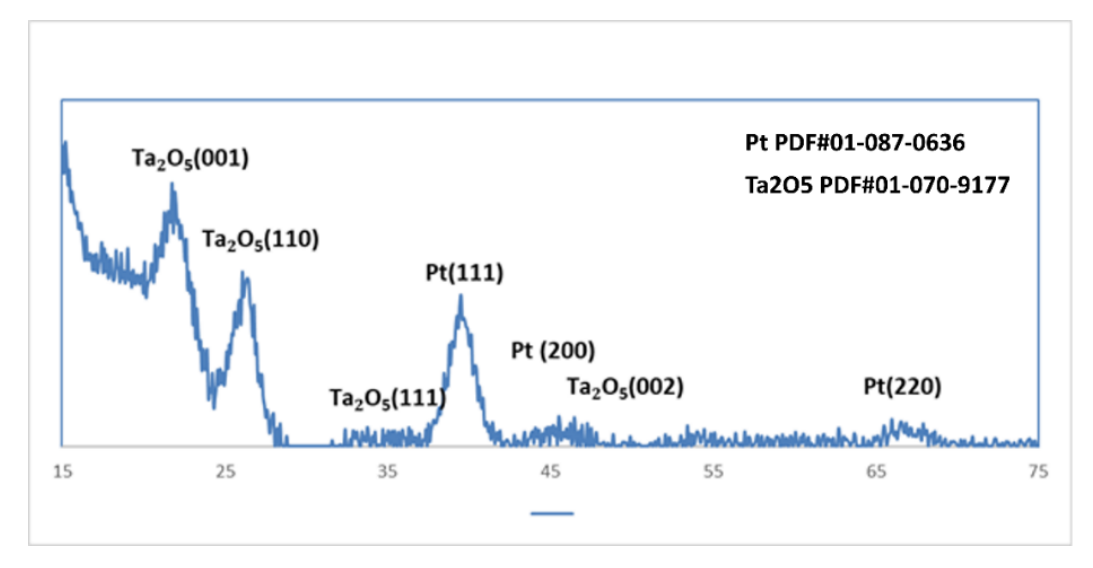

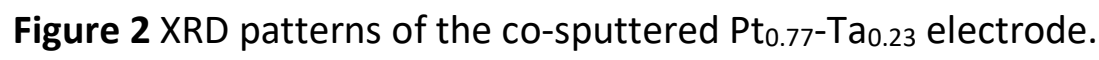


XPS studies of the co-sputtered $\mathrm{Pt}_{0.77}-\mathrm{Ta}_{0.23}$ catalyst, confirmed the oxidation state of tantalum (V). However, in the $\mathrm{Pt}_{0.77}-\mathrm{Ta}_{0.23}$ catalyst, the binding energy of Ta-4f shifted to $25.75 \mathrm{eV}$ compared to that of tantalum (V) oxide electrode prepared by sputter deposition, which was at $26.81 \mathrm{eV}$ (Table S2 and Figure S5). On the other hand, the binding energy associated with the Pt-4f peak in cosputtered $\mathrm{Pt}_{0.77}-\mathrm{Ta}_{0.23}$ was observed at $71.47 \mathrm{eV}$, exceeding slightly that of sputtered Pt which was $71.35 \mathrm{eV}$. These differences suggested a partial charge transfer from Pt to Ta in the sputtered films also reported in other studies $[13,14]$. However, we noticed that the Ta $4 \mathrm{f}$ binding energy shifted to a greater extent than the $\mathrm{Pt} 4 \mathrm{f}$ binding energy. This shift could be attributed to the atomic ratio of Ta: Pt at 28.8\%: $71.2 \%$, whereupon for each tantalum atom there were three to four platinum atoms. Consequently, the effect of the interaction can be expected to be more pronounced on each of the tantalum atoms than on the Pt atoms.

In the electro-oxidation of methanol, the strong adsorption of $\mathrm{CO}$ on Pt poisons the active catalytic sites inhibiting the electro-oxidation reaction. This strong adsorption comes from two electron donation mechanisms. Firstly, donation from the $\sigma$ bonding orbital of $\mathrm{CO}$ to the Pt $5 \mathrm{~d}$ orbital and then next by back-donation of the Pt $5 \mathrm{~d}$ orbital to the $\mathrm{CO}$ anti-bonding $2 \pi^{*}$ co orbitals. When the d-electron density decreased via charge transfer to $\mathrm{TaO}_{7 / 2}$, the Pt-CO binding energy can be expected to decrease. Thus, Ta can be expected to reduce the strength of adsorption of $\mathrm{CO}$ on platinum [20].

\subsection{Half-Cell Electrochemical Characterizations of Co-Sputtered Platinum-Tantalum}

The electrochemical characterization of the $\mathrm{Pt}_{0.77}-\mathrm{Ta}_{0.23}$ electrode was performed in a half-cell. The oxidation and reduction peaks in Figure 3 at $-0.6 \mathrm{~V}$ vs MSE correspond to the electro-sorption and electro-desorption of hydrogen on the platinum sites. The amount of charge under the hydrogen desorption peak, was used to calculate the electrochemically-active surface area of the

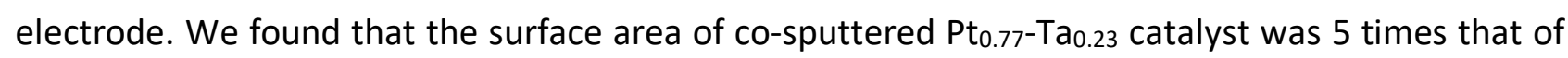
the sputtered platinum catalyst of the same loading of platinum as $\mathrm{Pt}_{0.77-} \mathrm{Ta}_{0.23}$.

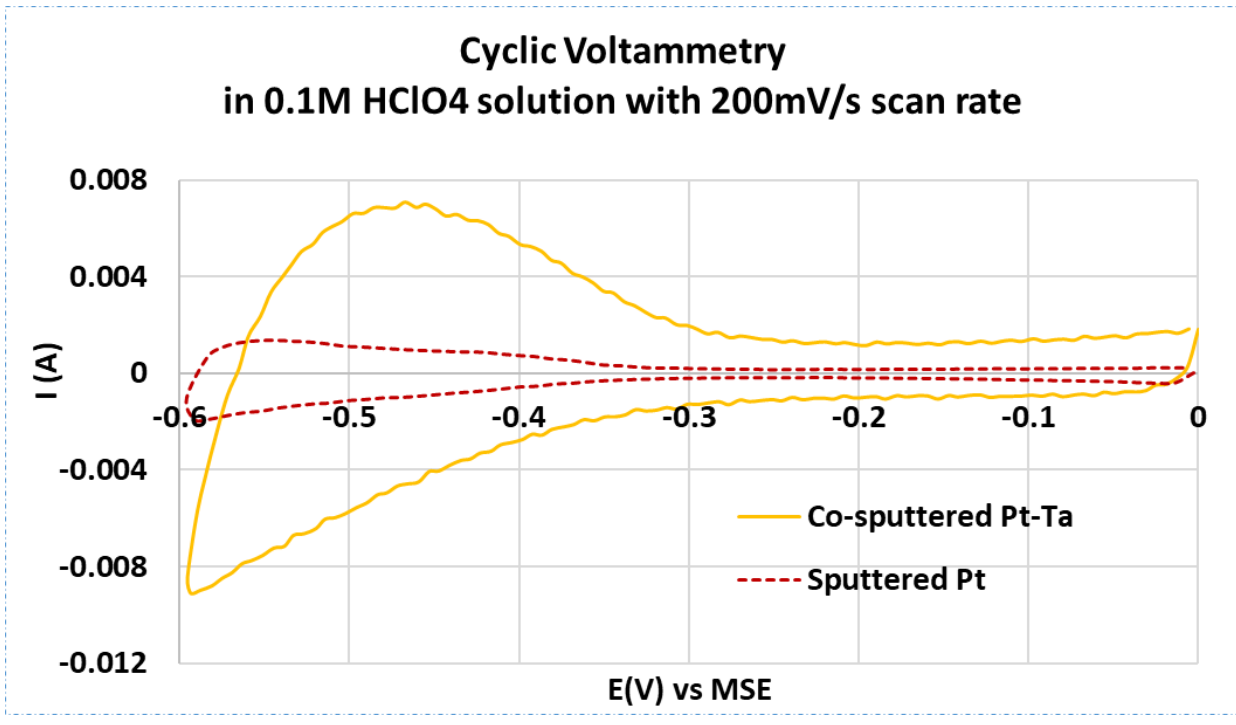

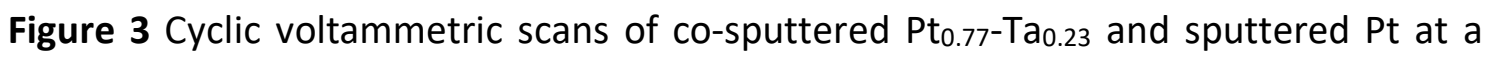
scanning rate of $200 \mathrm{mV} / \mathrm{s}$ in $0.1 \mathrm{M}$ perchloric acid. 
This increase in surface area could not be attributed to the increased volume added by tantalum to the catalyst for the following reason. According to the platinum to tantalum atomic ratio from EDX elemental composition analysis, and the density of Pt and $\mathrm{Ta}_{2} \mathrm{O}_{5}$ being $21.45 \mathrm{~g} / \mathrm{cm}^{2}$ and 8.2 $\mathrm{g} / \mathrm{cm}^{2}$, respectively, the estimated volume ratio of $\mathrm{Pt}$ to $\mathrm{Ta}_{2} \mathrm{O}_{5}$ was 1:0.83. The total volume of cosputtered $\mathrm{Pt}_{0.77}-\mathrm{Ta}_{0.23}$ could be expected to increase only about 1.83 times of the sputtered $\mathrm{Pt}$ sample with the same amount of Pt. The total platinum electrochemical surface area, however, was 5 times of sputtered Pt. We concluded that the morphology of Pt deposition had been changed by tantalum co-sputter deposition altering the growth of platinum deposits. To explain this observation, we proposed that in the sputtered platinum catalyst (Figure 4a), the platinum particles could grow on top of each of the other platinum particles whereas in the $\mathrm{Pt}_{1-\mathrm{x}}-\mathrm{Ta}_{\mathrm{x}}$ structure (Figure $4 \mathrm{~b}, \mathrm{c}$ ) with a moderate amount of tantalum, such growth was not possible allowing many more uncovered platinum sites to be present as shown in Figure $4 \mathrm{~d}$. The increased electrochemically active surface area of co-sputtered $\mathrm{Pt}_{1-\mathrm{x}}-\mathrm{Ta}_{\mathrm{x}}$ catalyst was also an indication of a better utilization of platinum materials.

a Pt Particle

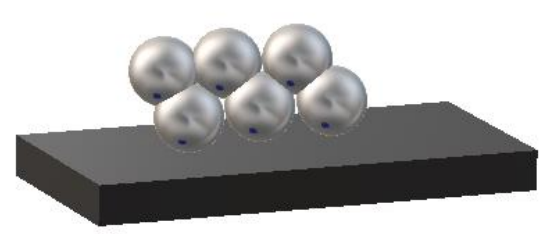

C $\mathrm{Ta}_{2} \mathrm{O}_{5}$ Particle Pt Particle

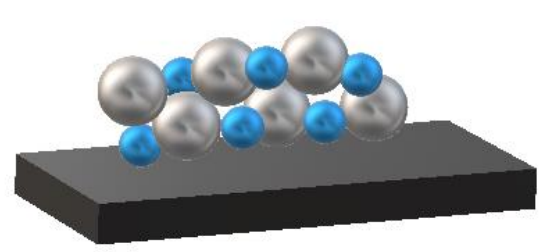

b $\mathrm{Ta}_{2} \mathrm{O}_{5}$ Particle Pt Particle

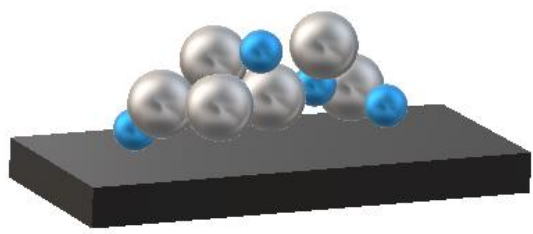

d $\mathrm{Ta}_{2} \mathrm{O}_{5}$ Particle Pt Particle

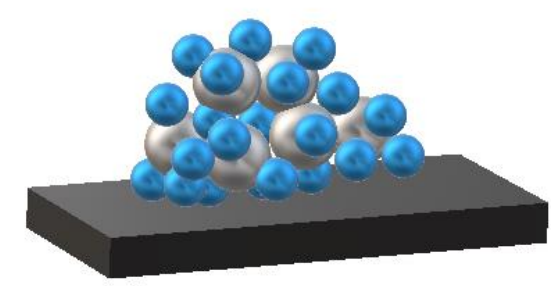

Figure 4 Illustrations of co-sputtered $\mathrm{Pt}_{1-\mathrm{x}}-\mathrm{Ta}_{\mathrm{x}}(0 \leq \mathrm{x}<1)$ catalysts with variant $\mathrm{Ta}$ to $\mathrm{Pt}$ atomic ratio (a) $x=0$, (b) $0<x<0.23$, (c) $x=0.23$ (b) $0.23<x<1$.

We also found that the electrochemically active surface area changed with the amount of Ta in the catalyst when the amount of platinum was maintained the same in all electrodes. The electrochemically active surface area (ECSA) and ECSA specific activity of co-sputtered $\mathrm{Pt}_{1-\mathrm{x}}-\mathrm{Ta}_{\mathrm{x}}$ $(0<x<0.49)$ was higher than for sputtered Pt catalyst (corresponding to $x=0)$. As shown in Figure 5 , the electrochemically active surface area of platinum first increased with increasing amount of Ta and reached a maximum at Ta: Pt atomic ratio equals 0.364 and then started decreasing. The maximum platinum surface area on a $2 \mathrm{~cm} \times 2 \mathrm{~cm}$ was $23.24 \mathrm{~cm}^{2}$. The plausible architecture in the 
film leading to the area increase is depicted in Figure 4. With increasing the amounts of Ta, the ECSA first increased because the Pt particles were better dispersed in the $\mathrm{Pt}_{1-\mathrm{x}}-\mathrm{Ta}_{\mathrm{x}}$ catalyst (Figure $4 \mathrm{~b}$ ) compared to the aggregated Pt particles in Pt catalysts; at the maximum value of electrochemically active surface area (Figure $4 \mathrm{c}$ ), tantalum particles helped platinum particles to disperse to the largest extent. In the meanwhile, all the platinum particles were still connected to the carbon substrate or other platinum particles. With further increase of Ta as in Figure $4 \mathrm{~d}$, some of the Pt particles could get isolated by the tantalum oxide particles. The poor electronic conductivity of the tantalum oxide could cause the decrease of access to the platinum particles and hence a decrease in the electrochemically active surface area of platinum.

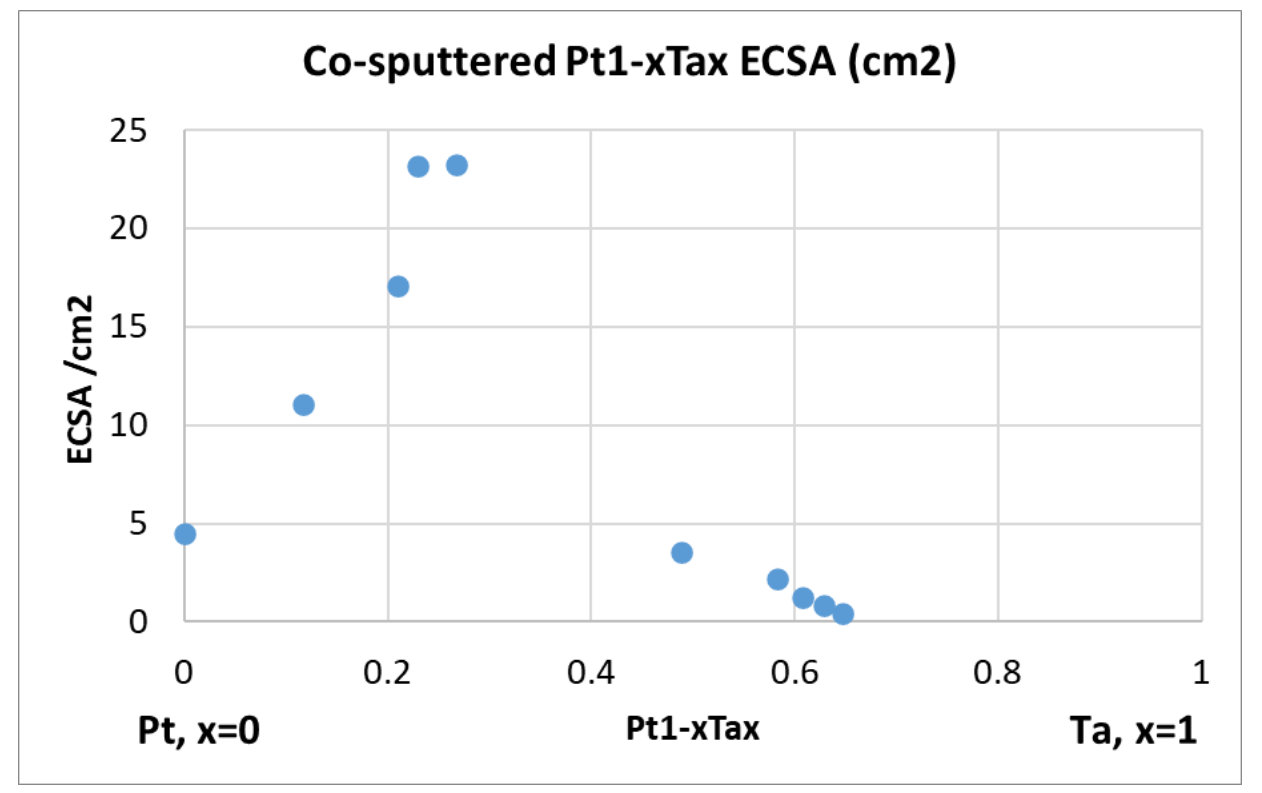

Figure 5 The effect of platinum to tantalum atomic ratio on the electrochemical surface area of co-sputtered $\mathrm{Pt}_{1-\mathrm{x}}-\mathrm{Ta}_{\mathrm{x}}(0<\mathrm{x}<1)$.

The electro-oxidation of methanol was studied at the sputter-deposited electrodes by slow-scan (quasi-steady-state) voltammetry and is shown in Figure 6. We compared the voltammetry of

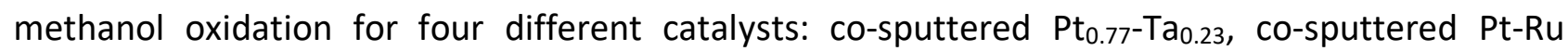
electrode with 1:1 atomic ratio, sputtered Pt and the commercial PtRu/C (commercial catalyst powder). The electrodes were anodically polarized in $1 \mathrm{M}$ solution of methanol in $0.1 \mathrm{M}$ perchloric acid over the potential range of $-0.5 \mathrm{~V}$ to $0 \mathrm{~V}$ vs MSE at the slow scan rate of $1 \mathrm{mV} / \mathrm{s}$. Onset potential of methanol oxidation in the anodic scan is a key metric for evaluating the catalyst activity [21]. We found that the commercial PtRu/C catalyst had a slightly higher onset potential compared with cosputtered Pt-Ru catalyst, while both these values of onset potential were close to $-0.3 \mathrm{~V}$ vs MSE. The onset potential of co-sputtered $\mathrm{Pt}_{0.77}-\mathrm{Ta}_{0.23}$ electrode was $-0.15 \mathrm{~V}$ and that for the sputtered Pt was $-0.125 \mathrm{~V}$. The onset potential for the methanol oxidation reaction was indicative of the potential when the $-\mathrm{OH}_{\mathrm{ads}}$ coverage by water adsorption began to increase. Under these conditions, the adsorbed intermediate from water, namely, $-\mathrm{OH}_{\mathrm{ads}}$, could react with adsorbed $-\mathrm{CO}_{\text {ads }}$ on the platinum sites leading to an oxidation current (Equation 3). These onset potential results were consistent with the water dissociation reaction that usually happens around $-0.3 \mathrm{~V}$ vs MSE on ruthenium, $-0.1 \mathrm{~V}$ on the platinum sites $[22,23]$. Thus, based on the onset potential observed for 


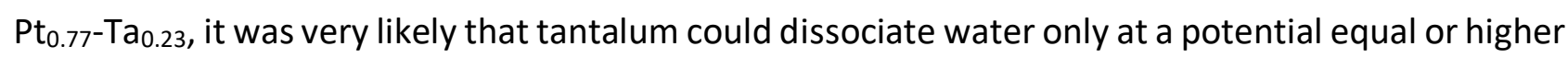
than $-0.15 \mathrm{~V}$ vs. MSE.

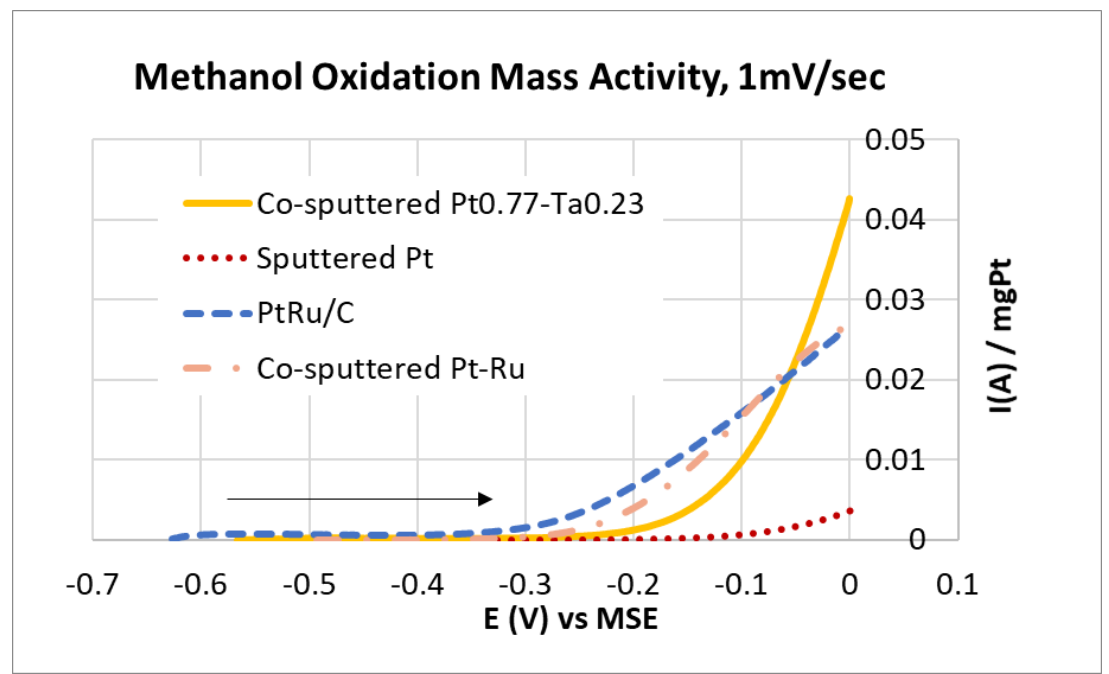

Figure 6 Pseudo-steady state methanol oxidation mass activities of co-sputtered $\mathrm{Pt}_{0.77^{-}}$ $\mathrm{Ta}_{0.23}$, co-sputtered Pt-Ru, sputtered $\mathrm{Pt}$ and $\mathrm{PtRu} / \mathrm{C}$ in $0.1 \mathrm{M}$ perchloric acid solution with $1 \mathrm{M}$ methanol.

The area specific activity for methanol oxidation is defined as the observed methanol oxidation current divided by the electrochemically active platinum surface area as determined from the hydrogen-desorption studies. In Figure 7 , the area specific activity of the $\mathrm{Pt}_{0.77}-\mathrm{Ta}_{0.23}$ increased with the electrode potential at a greater rate than $\mathrm{PtRu} / \mathrm{C}$, and the activity exceeded $\mathrm{PtRu} / \mathrm{C}$ at $-0.12 \mathrm{~V}$ vs MSE as we anodically polarized the electrode. The Pt electrode exhibited a low oxidation current as it was poisoned by the strong adsorption of $\mathrm{CO}$ adsorption on Pt sites. Upon reaching positive electrode potentials $>0 \mathrm{~V}$ vs. MSE, the water dissociation reaction was facilitated on the Pt sites and the adsorbed $\mathrm{CO}$ could be removed from the catalytic active surface to allow for further dissociation of methanol [24]. The methanol oxidation activities of co-sputtered $\mathrm{Pt}_{0.77}-\mathrm{Ta}_{0.23}$ catalyst at $-0.1 \mathrm{~V}$ and $0 \mathrm{~V}$ have been compared with PtRu/C and Pt in Table 2.

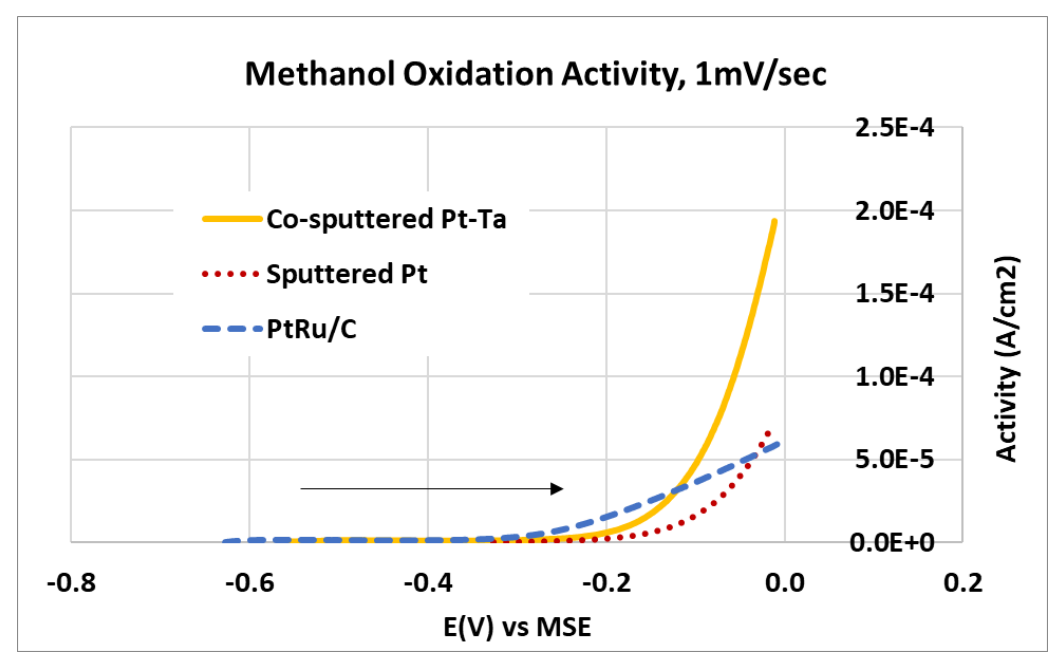

Figure 7 Pseudo-steady state methanol oxidation ECSA specific activities of co-sputtered $\mathrm{Pt}_{0.77}-\mathrm{Ta}_{0.23}$, sputtered $\mathrm{Pt}$ and $\mathrm{PtRu} / \mathrm{C}$ in $0.1 \mathrm{M}$ perchloric acid solution with $1 \mathrm{M}$ methanol. 


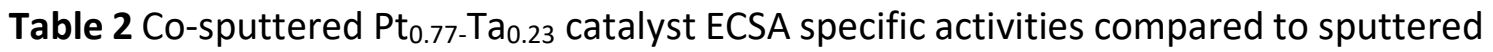
$\mathrm{Pt}$ and PtRu/C catalysts.

\begin{tabular}{lcc}
\hline Potential & Co-sputtered Pt-Ta catalyst electrochemical area specific activity \\
\hline At-0.1V vs MSE & 2.8 times of Pt & 1.2 times of PtRu/C \\
At OV vs MSE & 2.3 times of Pt & 3.2 times of PtRu/C \\
\hline
\end{tabular}

We also found that methanol oxidation activity of $\mathrm{Pt}_{1-\mathrm{x}}-\mathrm{Ta}_{\mathrm{x}}$ catalyst was affected by the amount of Ta in the catalysts. In Figure 8, the activity first increased with increasing the amount of Ta. We attributed this to more and more platinum catalytic sites being in contact with tantalum sites so that more bi-functional catalytic sites were generated. $\mathrm{Pt}_{0.77}-\mathrm{Ta}_{0.23}$ had the highest activity. However, the activity decreased with further increase in tantalum content. We ascribed this to the Pt particles becoming isolated due to the higher content of tantalum oxide particles. Thus, the specific activity of co-sputtered $\mathrm{Pt}_{1-\mathrm{x}}-\mathrm{Ta}_{\mathrm{x}}(0<\mathrm{x}<0.49)$ was higher than sputtered $\mathrm{Pt}$ catalyst, corresponding to $\mathrm{x}=0$.

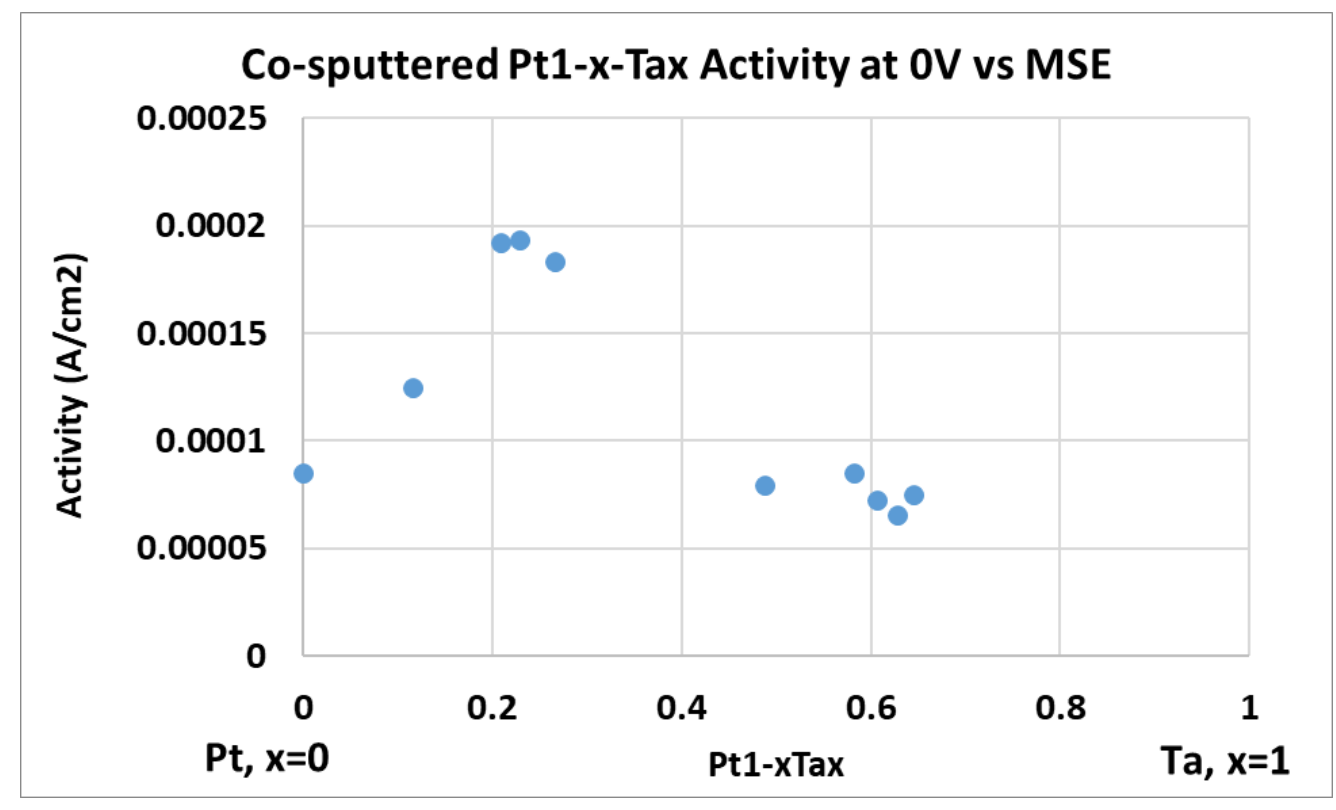

Figure 8 The effect of co-sputtered $\mathrm{Pt}_{1-\mathrm{x}}-\mathrm{Ta}_{\mathrm{x}}$ catalysts composition on the methanol oxidation ECSA specific activity.

To test the stability of the electrocatalyst with the highest specific activity (the $\mathrm{Pt}_{0.77-\mathrm{Ta}_{0.23}}$ electrode), we carried out steady-state polarization tests at a relatively positive potential of $-0.1 \mathrm{~V}$

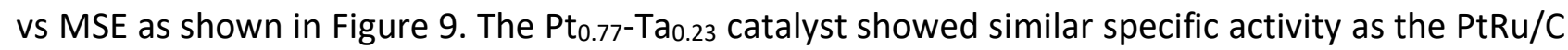
after holding at $-0.1 \mathrm{~V}$ vs MSE for 1 hour. We attributed the gradual decrease and stabilization of

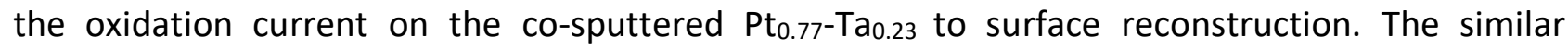
sputtered electrodes including those with Pt-Ru also exhibited the same type of decrease before stabilization as shown in Figure S6. Upon stabilization the rate of change of current after 3600 seconds was $0.0029 \%$ per second for co-sputtered $\mathrm{Pt}_{0.77-\mathrm{Ta}_{0.23}}$ while that for the co-sputtered Pt-Ru

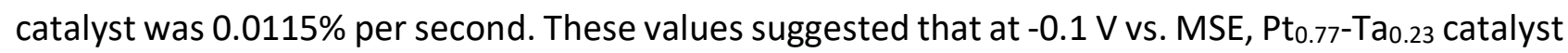
resisted deactivation better than the co-sputtered Pt-Ru catalyst. 


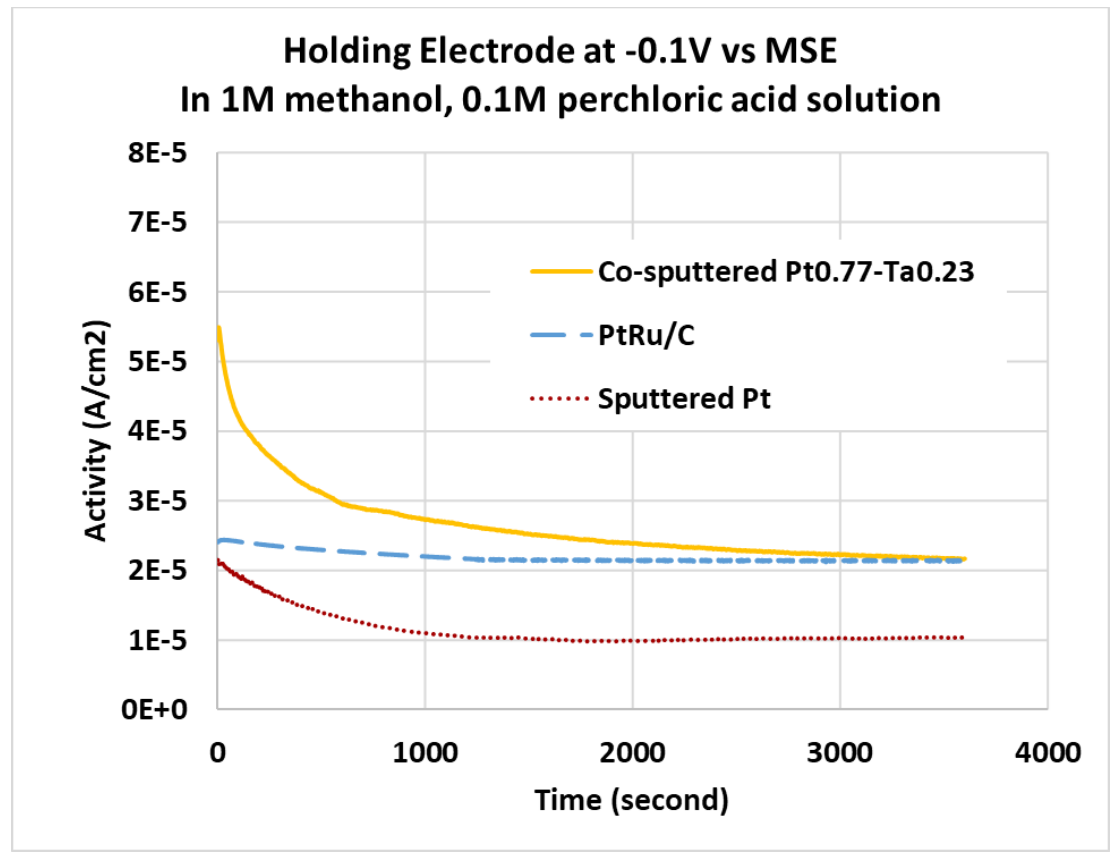

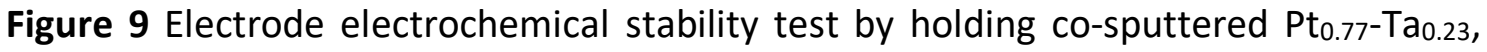
PtRu/C and sputtered Pt electrodes at -0.1 V vs MSE for 1 hour.

\subsection{Methanol Oxidation Mechanism of Co-Sputtered Platinum-Tantalum Catalysts}

Tafel slopes of co-sputtered $\mathrm{Pt}_{0.77}-\mathrm{Ta}_{0.23}$, sputtered-Pt and $\mathrm{PtRu} / \mathrm{C}$ electrodes are compared in

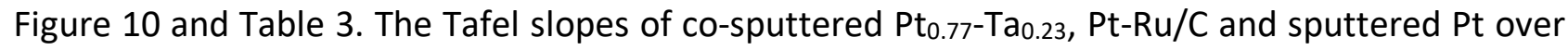
the range of $-0.3 \mathrm{~V}<\mathrm{V}<-0.15 \mathrm{~V}$ vs MSE potential region were similar indicating similar kinetic behavior, with a rate-determining step corresponding to a one-electron transfer process [25]. The Tafel slope of $\mathrm{PtRu} / \mathrm{C}$ in the range of $-0.15 \mathrm{~V}<\mathrm{V}<0 \mathrm{~V}$ vs MSE was higher than $-0.3 \mathrm{~V}$ to $-0.15 \mathrm{~V}$, suggesting a change in the mechanism. Earlier research showed that the limiting currents of PtRu/C in this potential region are not mass-transfer controlled and cannot be enhanced by changing the rotating speed of the rotating disk electrode in a half-cell experiment [26].

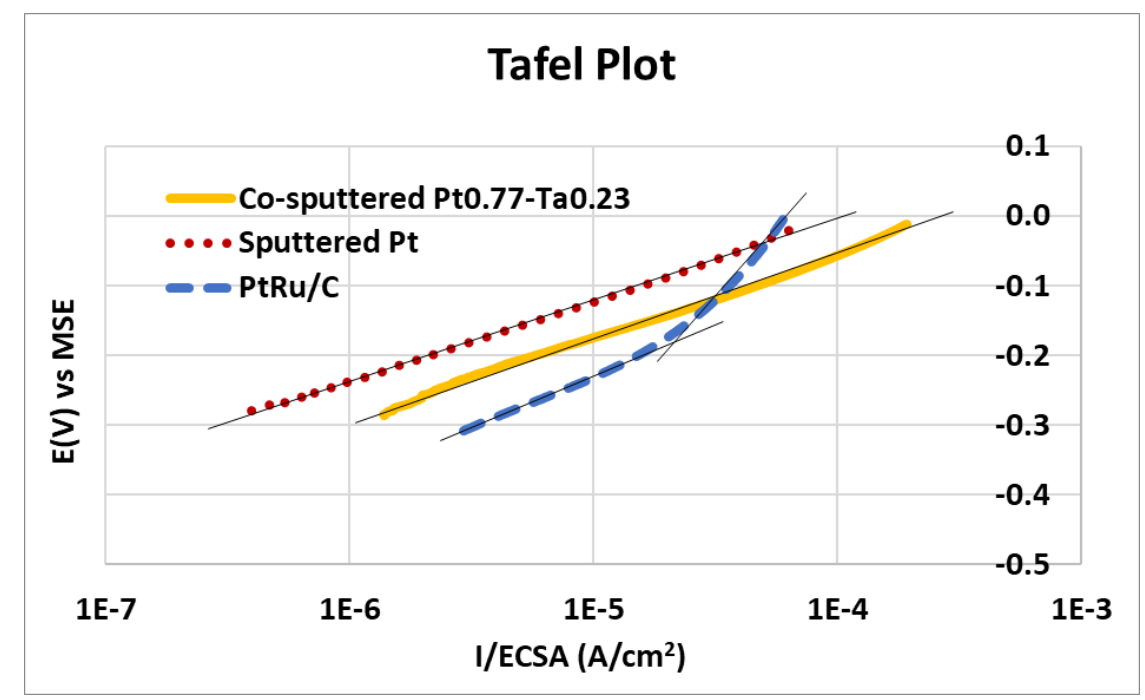

Figure 10 Methanol oxidation reaction Tafel plots of co-sputtered $\mathrm{Pt}_{0.77}-\mathrm{Ta}_{0.23}$, sputtered $\mathrm{Pt}$ and PtRu/C. 


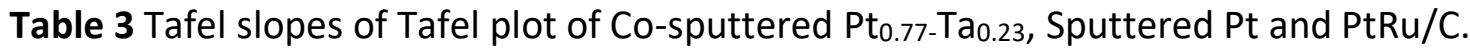

\begin{tabular}{lll}
\hline Electrode & Tafel slope & Potential Range \\
\hline Co-sputtered $\mathrm{Pt}_{0.77}-\mathrm{Ta}_{0.23}$ & $119 \mathrm{mV} / \mathrm{dec}$ & $-0.3 \mathrm{~V}<\mathrm{V}<0 \mathrm{~V}$ \\
Sputtered Pt & $117 \mathrm{mV} / \mathrm{dec}$ & $-0.3 \mathrm{~V}<\mathrm{V}<0 \mathrm{~V}$ \\
& $143 \mathrm{mV} / \mathrm{dec}$ & $-0.3 \mathrm{~V}<\mathrm{V}<-0.15 \mathrm{~V}$ \\
$\mathrm{PtRu} / \mathrm{C}$ & $376 \mathrm{mV} / \mathrm{dec}$ & $-0.15 \mathrm{~V}<\mathrm{V}<0 \mathrm{~V}$ \\
\hline
\end{tabular}

We also found that changing the amount of tantalum in the catalyst affected the Tafel Slope for methanol oxidation as shown in Figure 11. The Tafel slope at low Ta percentage was $120 \mathrm{mV} / \mathrm{dec}$, that suggested the rate-determining step to be a one-electron transfer step. As previously discussed, it was attributed to the surface recombination step. At higher values of Ta percentage, the Tafel slope first increased to $300 \mathrm{mV} / \mathrm{dec}$. The most likely rate-determining step at these potentials was the step of methanol dissociation. Further increase in the percentage of Ta resulted in a Tafel slope of about $500 \mathrm{mV}$. XRD studies on co-sputtered $\mathrm{Pt}_{0.35}-\mathrm{Ta}_{0.65}$ and $\mathrm{Pt}_{0.43}-\mathrm{Ta}_{0.57}$ electrodes suggested that for Ta content of $>60 \%$ the surface was rich in $\mathrm{Ta}_{2} \mathrm{O}_{5}$ and $\mathrm{TaO}_{2}$ as shown in Figure 12. The insulating property of these oxides would then explain the anomalously high Tafel slope.

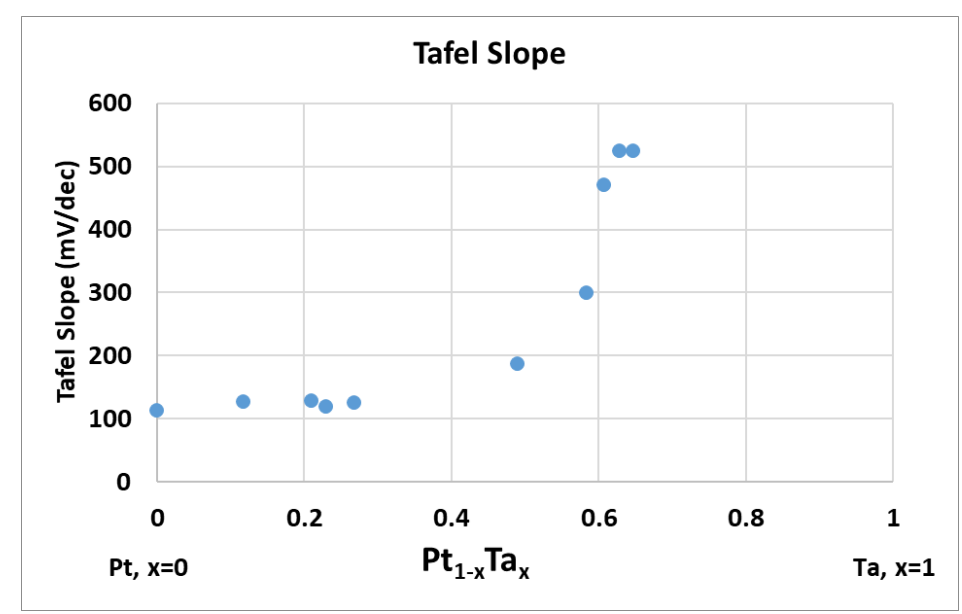

Figure 11 The effect of $\mathrm{Pt}_{1-\mathrm{x}}-\mathrm{Ta}_{\mathrm{x}}$ catalysts composition on the methanol oxidation Tafel slope. 


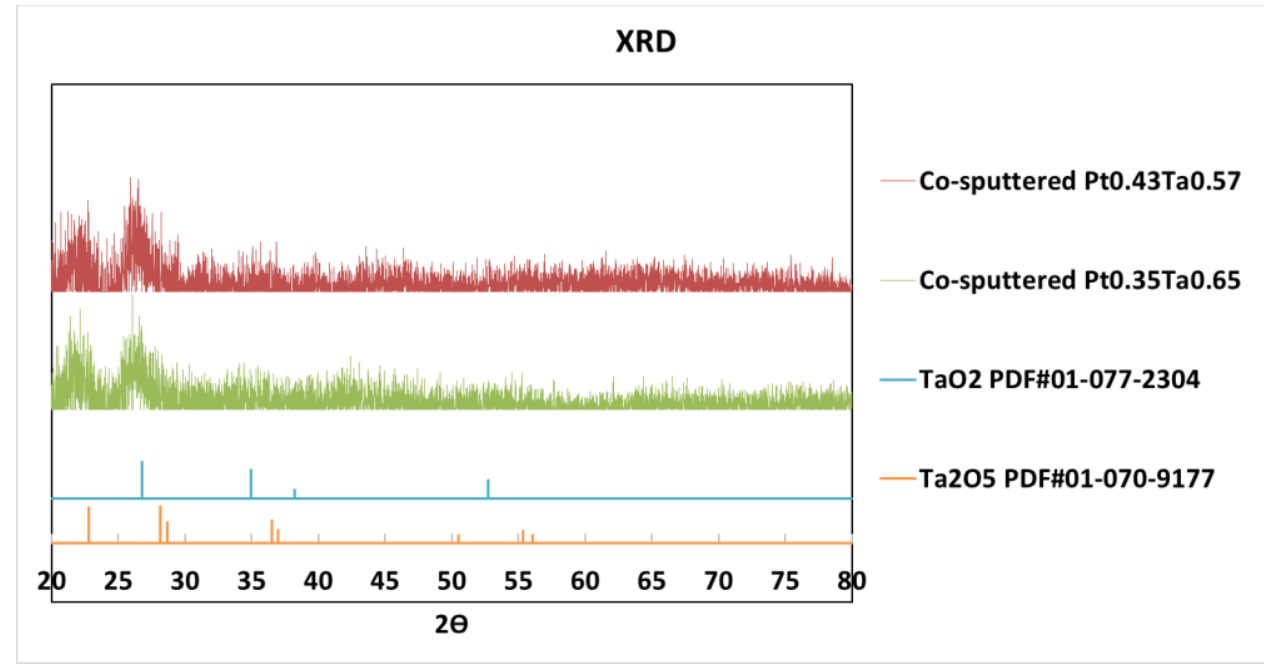

Figure 12 XRD pattens of co-sputtered $\mathrm{Pt}_{0.35}-\mathrm{Ta}_{0.65}$ and $\mathrm{Pt}_{0.43}-\mathrm{Ta}_{0.57}$ electrode.

As we discussed earlier, the specific activity of co-sputtered $\mathrm{Pt}_{1-\mathrm{x}}-\mathrm{Ta}_{\mathrm{x}}(0<\mathrm{x}<0.49)$ was higher than sputtered Pt. Further, the decrease in onset potential also suggested that Ta played an active role in enhancing the kinetics of the methanol oxidation reaction. Based on the metal oxides' ability to activate the water molecule and the Tafel Slope values, we propose the bi-functional mechanism on $\mathrm{Pt}_{1-\mathrm{x}}-\mathrm{Ta}_{\mathrm{x}}$ catalysts shown schematically in Figure 13 and in equations 4-6. The rate determining step is the one-electron surface recombination step.

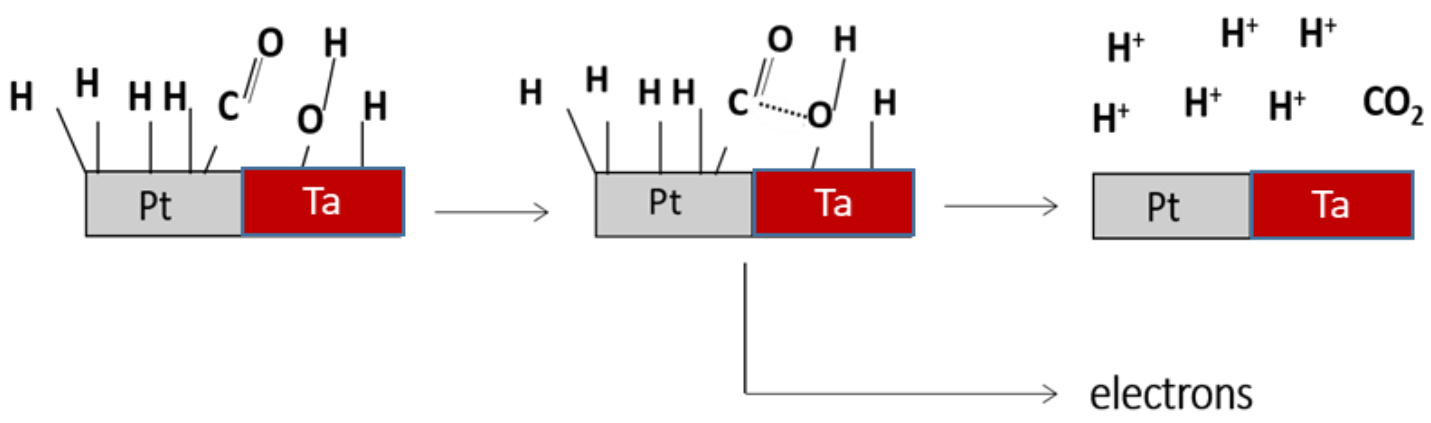

Figure 13 Co-sputtered $\mathrm{Pt}_{1-\mathrm{x}}-\mathrm{Ta}_{\mathrm{x}}$ catalyst as a bi-functional catalyst for methanol oxidation.

$$
\begin{gathered}
\text { Methanol Dissociation: } \mathrm{Pt}+\mathrm{CH}_{3} \mathrm{OH} \rightarrow \mathrm{Pt}-\mathrm{H}_{\mathrm{ads}}+\mathrm{Pt}-\mathrm{CO}_{\mathrm{ads}} \\
\text { Water Dissociation: } \mathrm{TaO}_{\mathrm{x}}+\mathrm{H}_{2} \mathrm{O} \rightarrow \mathrm{TaO}_{\mathrm{x}}-\mathrm{H}_{\text {ads }}+\mathrm{TaO}_{\mathrm{x}}-\mathrm{OH}_{\mathrm{ads}} \\
\text { Surface Recombination: } \mathrm{Pt}-\mathrm{CO}_{\mathrm{ads}}+\mathrm{TaO}_{\mathrm{x}}-\mathrm{OH}_{\mathrm{ads}} \rightarrow \mathrm{Pt}+\mathrm{TaO}_{\mathrm{x}}+\mathrm{CO}_{2}+\mathrm{H}^{+}+\mathrm{e}^{-}
\end{gathered}
$$

\subsection{Full-Cell Performance of the Membrane-Electrode Assemblies}

Figure 14 shows the cell voltage and cell power density as a function of the current density for direct methanol fuel cells that use co-sputtered $\mathrm{Pt}_{0.77}-\mathrm{Ta}_{0.23}$ and $\mathrm{PtRu} / \mathrm{C}$ as anode catalysts. The loading of platinum in PtRu/C electrode was $0.67 \mathrm{mg}$, and that of co-sputtered $\mathrm{Pt}_{0.77}-\mathrm{Ta}_{0.23}$ electrode 
was $0.69 \mathrm{mg}$. The full cells with both these anode catalysts were studied at $90^{\circ} \mathrm{C}, 80^{\circ} \mathrm{C}$ and $60^{\circ} \mathrm{C}$ in $1 \mathrm{M}$ methanol with oxygen flowing through the positive electrode at $2 \mathrm{lpm}$ and at $1.7 \mathrm{~atm}$.
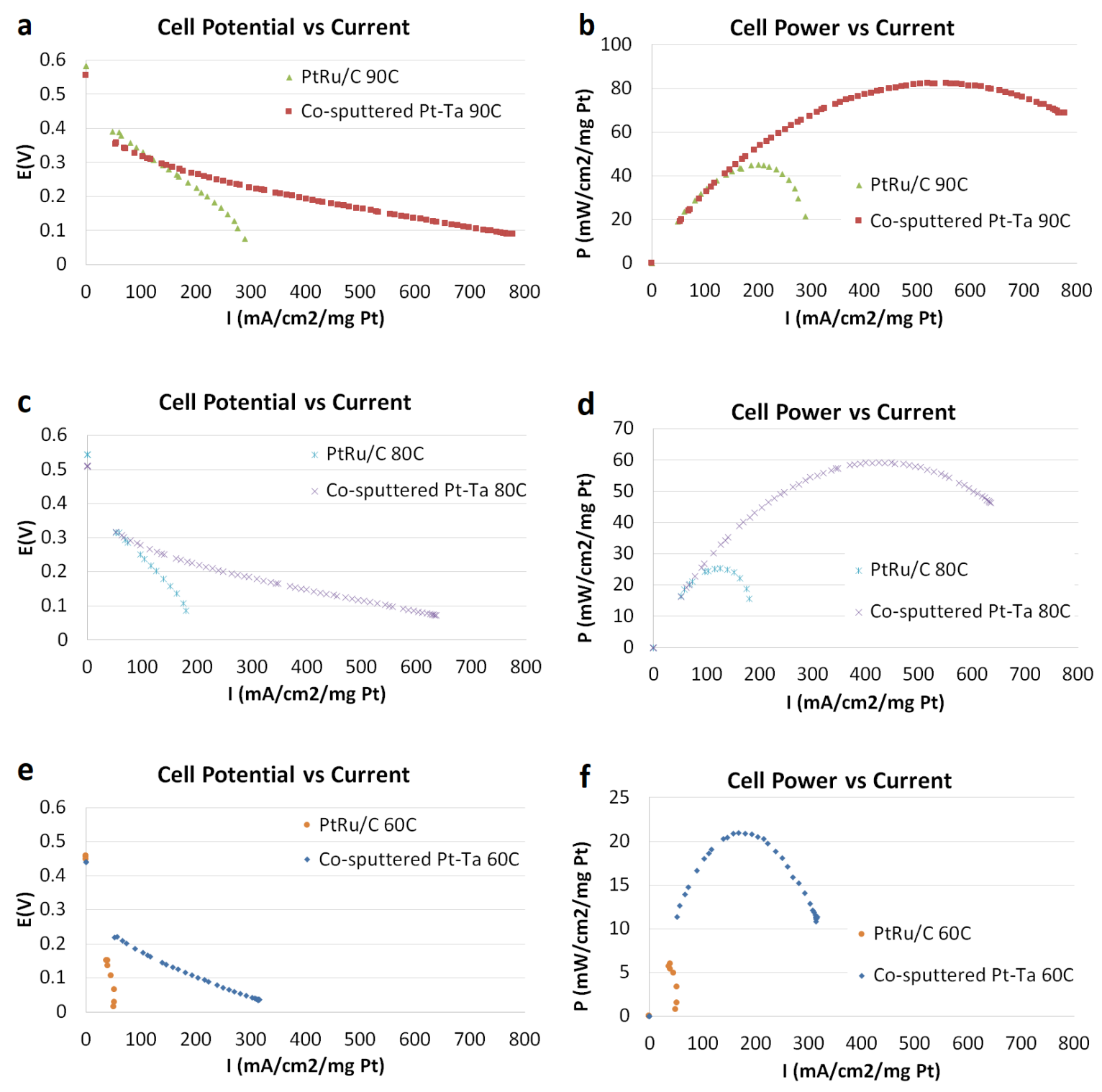

Figure 14 Cell voltage and cell power density of the direct methanol fuel cells with co-

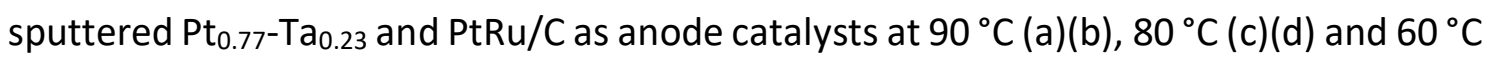
(e)(f), in $1 \mathrm{M}$ methanol with $2 \mathrm{Lpm}$ oxygen at $1.7 \mathrm{~atm}$.

The maximum power densities of the cells with $\mathrm{Pt}_{0.77}-\mathrm{Ta}_{0.23}$ were higher than that with $\mathrm{PtRu} / \mathrm{C}$ at all the temperatures studied (Table 4). The best performance for both $\mathrm{PtRu} / \mathrm{C}$ and $\mathrm{Pt}_{0.77-\mathrm{Ta}_{0.23} \text { were }}$ attained at $90{ }^{\circ} \mathrm{C}$. Current densities as high as $300 \mathrm{~mA} / \mathrm{cm}^{2}$ could be supported on the Pt-Ta catalysts. At a cell voltage of $300 \mathrm{mV}$, the current normalized for platinum loading was $139 \mathrm{~mA} /\left(\mathrm{cm}^{2} \times \mathrm{mg}_{\mathrm{Pt}}\right.$ ) (at $\left.95.6 \mathrm{~mA} / \mathrm{cm}^{2}\right)$. The maximum power density was achieved by $\mathrm{Pt}_{0.77}-\mathrm{Ta}_{0.23}$ at $82 \mathrm{~mA} /\left(\mathrm{cm}^{2} \times \mathrm{mg}_{\mathrm{Pt}}\right)$ $\left(57 \mathrm{~mW} / \mathrm{cm}^{2}\right.$ with a platinum loading of only $\left.0.028 \mathrm{mg} / \mathrm{cm}^{2}\right), 1.82$ times of that of a state-of-the-art $\mathrm{PtRu} / \mathrm{C}$ catalyst. This result is comparable to the work of Witham et al, where the PtRu MEA made by sputter deposition showed a power density of $75 \mathrm{~mW} / \mathrm{cm}^{2}$ at a platinum loading of $0.02 \mathrm{mg} / \mathrm{cm}^{2}{ }^{1}$ 
The maximum current of $\mathrm{Pt}_{0.77}-\mathrm{Ta}_{0.23}$ was $778 \mathrm{~mA} /\left(\mathrm{cm}^{2}-\mathrm{mg}_{\mathrm{Pt}}\right), 2.7$ times that of $\mathrm{PtRu} / \mathrm{C}$. Although we did not collect any long-term durability data, we must note each run of our current-voltage tests was carried out over a 20 minutes period. During these tests, the electrodes experienced temperature in the range of 60-90 degrees Celsius and current densities in the range of 100-600 $\mathrm{mA} / \mathrm{cm}^{2}$. No noticeable performance change was noticed in these tests. These results suggested that the catalysts were durable at least in the short term.

Table 4 Maximum power densities and current densities of co-sputtered $\mathrm{Pt}_{0.77-\mathrm{Ta}_{0.23} \text { and }}$ PtRu/C.

\begin{tabular}{|c|c|c|c|c|c|}
\hline MEAs & & & $90^{\circ} \mathrm{C}$ & $80^{\circ} \mathrm{C}$ & $60^{\circ} \mathrm{C}$ \\
\hline \multirow{2}{*}{$\begin{array}{l}\text { Co-sputtered } \\
\mathrm{Ta}_{0.23}\end{array}$} & \multirow[t]{2}{*}{$\mathrm{Pt}_{0.77^{-}}$} & $\begin{array}{l}\text { Maximum Power Density } \\
\mathrm{mW} / \mathrm{cm}^{2} / \mathrm{mg}_{\mathrm{Pt}}\end{array}$ & 82 & 59 & 21 \\
\hline & & $\begin{array}{l}\text { Maximum Current Density } \\
\mathrm{mA} / \mathrm{cm}^{2} / \mathrm{mg}_{\mathrm{Pt}}\end{array}$ & 778 & 635 & 314 \\
\hline \multirow{2}{*}{ PtRu/C } & & $\begin{array}{l}\text { Maximum Power Density } \\
\mathrm{mW} / \mathrm{cm}^{2} / \mathrm{mg}_{\mathrm{Pt}}\end{array}$ & 45 & 25 & 6.0 \\
\hline & & $\begin{array}{l}\text { Maximum Current Density } \\
\mathrm{mA} / \mathrm{cm}^{2} / \mathrm{mg}_{\mathrm{Pt}}\end{array}$ & 289 & 180 & 50.1 \\
\hline
\end{tabular}

\section{Conclusion}

In this paper, a series of thin film $\mathrm{Pt}_{1-\mathrm{x}}-\mathrm{Ta}_{\mathrm{x}}$ catalysts were prepared by the sputter deposition method. The method can also be applied to any supporting electrode substrate. Such a method is also amenable for rapid throughput and scale-up as indicated by the work of $3 \mathrm{M}$ on sputter-

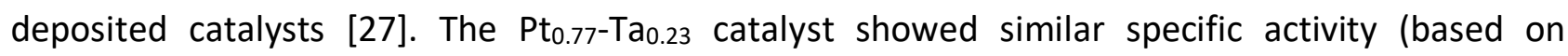
electrochemically active area) comparable to commercial-available PtRu/C catalysts. We found that the atomic ratio of platinum to tantalum in the catalyst affected the platinum-normalized methanol oxidation activity and suggested that in the $\mathrm{Pt}_{1-\mathrm{x}}-\mathrm{Ta}_{\mathrm{x}}(0<\mathrm{x}<0.49)$ catalysts the methanol oxidation reaction was activated by tantalum. The surface oxides of tantalum can activate water molecules and hence facilitate the process of removing carbon monoxide from platinum sites. Direct methanol fuel cells with $\mathrm{Pt}_{0.77}-\mathrm{Ta}_{0.23}$ catalyst achieved a platinum-normalized power density of $82 \mathrm{~mW} /\left(\mathrm{cm}^{2}\right.$ $\mathrm{mg} \mathrm{pt}_{\mathrm{t}}$ at 90 degrees Celsius which is 1.82 times of $\mathrm{PtRu} / \mathrm{C}$ catalyst. As per our knowledge, this is the first time a tantalum-containing catalyst has been tested in a membrane-electrode assembly (MEA) for methanol oxidation. In the supplementary materials (Table S3) we provide a summary of the MEA performance of binary Pt-X catalysts synthesized by sputter-deposition and tested under comparable conditions in an effort to provide some benchmarking on the performance of the catalysts studied in this work. The scalability of sputter-deposition method and the lower noble metal content are beneficial for the practical use of these new catalysts.

\section{Acknowledgments}

The authors thank Dr A. Manivannan for his help with the XPS measurement. The authors thank Dr Bo Yang at University of Southern California for his assistance with setting up the testing systems. 
The instrumentation support from the staff at Loker Hydrocarbon Institute at University of Southern California is acknowledged.

\section{Additional Materials}

The following additional materials are uploaded at the page of this paper.

1. Figure S1: SEM images of Toray paper TGPH-060 (Left) and AvCarb paper MGL 190 (Right).

2. Table S1: The properties of carbon fiber paper TGPH-060 and AvCarb MGL.

3. Figure S2: The highest resolution SEM image of co-sputtered $\mathrm{Pt}_{0.77}-\mathrm{Ta}_{0.23}$ electrode.

4. Figure S3: SEM image of co-sputtered $\mathrm{Pt}_{0.43}-\mathrm{Ta}_{0.57}$ electrode (Left) and co-sputtered $\mathrm{Pt}_{0.37^{-}}$ Ta 0.63 electrode (Right).

5. Figure S4: EDX elemental mapping of (a) platinum and (b) tantalum.

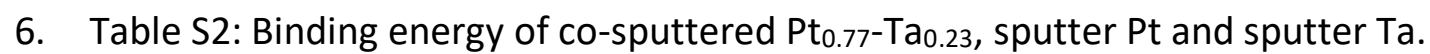

7. Figure S5: Co-sputter Pt-Ta XPS spectra, (a) Ta-4f and (b) Pt-4f binding energy, XPS spectra were corrected using carbon spectra as a standard

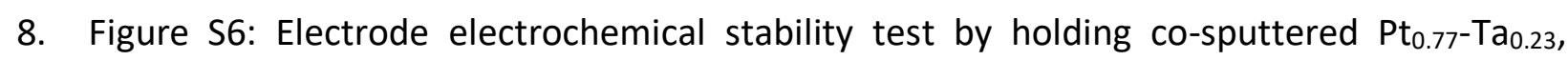
PtRu/C, Co-sputtered Pt-Ru and sputtered Pt electrodes at -0.1V vs MSE for one hour

9. Table S3: A summary of the methanol oxidation performance of MEAs with binary Pt-X catalyst synthesized by sputter deposition in current and previous research work.

\section{Author Contributions}

Dr Dan Fang performed the experiments and the analysis. Professor Sri R Narayan supervised her research.

\section{Funding}

This work was supported by Loker Hydrocarbon Institute at University of Southern California.

\section{Competing Interests}

The authors have declared that no competing interests exist.

\section{References}

1. Olah GA. The methanol economy. Chem Eng News. 2003; 81: 5.

2. Surampudi S, Narayanan SR, Vamos E, Frank H, Halpert G, LaConti AN, et al. Advances in direct oxidation methanol fuel cells. J Power Sources. 1994; 47: 377-385.

3. McGrath KM, Prakash GS, Olah GA. Direct methanol fuel cells. J Ind Eng Chem. 2004; 10: 10631080.

4. Prakash GKS, Olah GA, Smart MC, Narayanan SR, Wang QS, Surumpudi S, et al. Novel polymer electrolyte membranes for use in methanol fuel cells. Washington: US Patent; 1998; W01998022989A1.

5. Prakash GS, Krause FC, Viva FA, Narayanan SR, Olah GA. Study of operating conditions and cell design on the performance of alkaline anion exchange membrane based direct methanol fuel 
cells. J Power Sources. 2011; 196: 7967-7972.

6. Valdez TI, Narayanan SR. Effect of fabrication technique on direct methanol fuel cells designed to operate at low airflow. ECS Proc Volumes. 2002; 2002: 506.

7. Whitacre JF, Valdez T, Narayanan SR. Investigation of direct methanol fuel cell electrocatalysts using a robust combinatorial technique. J Electrochem Soc. 2005; 152: A1780-A1789.

8. Arico AS, Srinivasan S, Antonucci V. DMFCs: From fundamental aspects to technology development. Fuel Cells. 2001; 1: 133-161.

9. Moura AS, Fajín JL, Mandado M, Cordeiro MN. Ruthenium-platinum catalysts and direct methanol fuel cells (DMFC): A review of theoretical and experimental breakthroughs. Catalysts. 2017; 7: 47.

10. Piela P, Eickes $C$, Brosha E, Garzon F, Zelenay P. Ruthenium crossover in direct methanol fuel cell with Pt-Ru black anode. J Electrochem Soc. 2004; 151: A2053.

11. Valdez TI, Firdosy S, Koel B, Narayanan SR. Investigation of ruthenium dissolution in advanced membrane electrode assemblies for direct methanol based fuel cell stacks. ECS Trans. 2006; 1: 293-303.

12. Tague ME, Gregoire JM, Legard A, Smith E, Dale D, Hennig R, et al. High Throughput thin film Pt$M$ alloys for fuel electrooxidation: Low concentrations of $M(M=S n, T a, W, M o, R u, F e, I n, P d$, $\mathrm{Hf}, \mathrm{Zn}, \mathrm{Zr}, \mathrm{Nb}, \mathrm{Sc}, \mathrm{Ni}, \mathrm{Ti}, \mathrm{V}, \mathrm{Cr}, \mathrm{Rh})$. J Electrochem Soc. 2012; 159: F880.

13. Masud J, Alam MT, Awaludin Z, El-Deab MS, Okajima T, Ohsaka T. Electrocatalytic oxidation of methanol at tantalum oxide-modified Pt electrodes. J Power Sources. 2012; 220: 399-404.

14. Gregoire JM, Tague ME, Cahen S, Khan S, Abruna HD, DiSalvo FJ, et al. Improved fuel cell oxidation catalysis in $\mathrm{Pt}_{1-\mathrm{x}} \mathrm{Ta}_{\mathrm{x}}$. Chem Mater. 2010; 22: 1080-1087.

15. Park KW, Sung YE. Pt nanostructured electrode encapsulated by a tantalum oxide for thin-film fuel cell. J Vac Sci Technol B Microelectron Nanom Struct. 2004; 22: 2628-2631.

16. Wang F, Zhao H, Liang J, Li T, Luo $Y$, Lu S, et al. Magnetron sputtering enabled synthesis of nanostructured materials for electrochemical energy storage. J Mater Chem A. 2020; 8: 2026020285.

17. Liang J, Liu Q, Li T, Luo Y, Lu S, Shi X, et al. Magnetron sputtering enabled sustainable synthesis of nanomaterials for energy electrocatalysis. Green Chem. 2021; 23: 2834-2867.

18. Trasatti S, Petrii OA. Real surface area measurements in electrochemistry. Pure Appl Chem. 1991; 63: 711-734.

19. Patterson AL. The Scherrer formula for X-ray particle size determination. Phys Rev. 1939; 56 : 978-982.

20. Blyholder G. Molecular orbital view of chemisorbed carbon monoxide. J Phys Chem C. 1964; 68: 2772-2777.

21. Geng D, Lu G. Dependence of onset potential for methanol electrocatalytic oxidation on steric location of active center in multicomponent electrocatalysts. J Phys Chem C. 2007; 111: 1189711902.

22. Kakati N, Maiti J, Lee SH, Jee SH, Viswanathan B, Yoon YS. Anode catalysts for direct methanol fuel cells in acidic media: Do we have any alternative for Pt or Pt-Ru? Chem Rev. 2014; 114: 12397-12429.

23. Wasmus S, Küver A. Methanol oxidation and direct methanol fuel cells: A selective review. J Electroanal Chem. 1999; 461: 14-31.

24. Liu H, Zhang J. Electrocatalysis of direct methanol fuel cells: From fundamentals to applications. 
Weinheim: Wiley-VCH Verlag GmbH \& Co. KGaA; 2009.

25. Vidaković T, Christov M, Sundmacher K. Rate expression for electrochemical oxidation of methanol on a direct methanol fuel cell anode. J Electroanal Chem. 2005; 580: 105-121.

26. Li L, Xing Y. Methanol electro-oxidation on Pt-Ru alloy nanoparticles supported on carbon nanotubes. Energies. 2009; 2: 789-804.

27. Debe MK. Electrocatalyst approaches and challenges for automotive fuel cells. Nature. 2012; 486: 43-51.

28. Witham CK, Chun W, Valdez TI, Narayanan SR. Performance of direct methanol fuel cells with sputter-deposited anode catalyst layers. Electrochem Solid State Lett. 2000; 3: 497-500.

29. Caillard A, Coutanceau C, Brault P, Mathias J, Léger JM. Structure of Pt/C and PtRu/C catalytic layers prepared by plasma sputtering and electric performance in direct methanol fuel cells (DMFC). J Power Sources. 2006; 162: 66-73.

30. Jeong W, Cho GY, Cha SW, Park T. Surface roughening of electrolyte membrane for Pt-and Rusputtered passive direct methanol fuel cells. Materials. 2019; 12: 3969.

31. Nakashima T, Saito H, Murano K, Fukuhara C, Sudoh M. Design of multi-layer anode for direct methanol fuel cell. Electrochemistry. 2011; 79: 361-363.

32. Xinyao Y, Zhongqing J, Yuedong M. Preparation of anodes for DMFC by Co-sputtering of platinum and ruthenium. Plasma Sci Technol. 2010; 12: 224.

33. Park KW, Lee YW, Sung YE. Nanostructure catalysts prepared by multi-sputtering deposition process for enhanced methanol electrooxidation reaction. Appl Catal B. 2013; 132: 237-244.

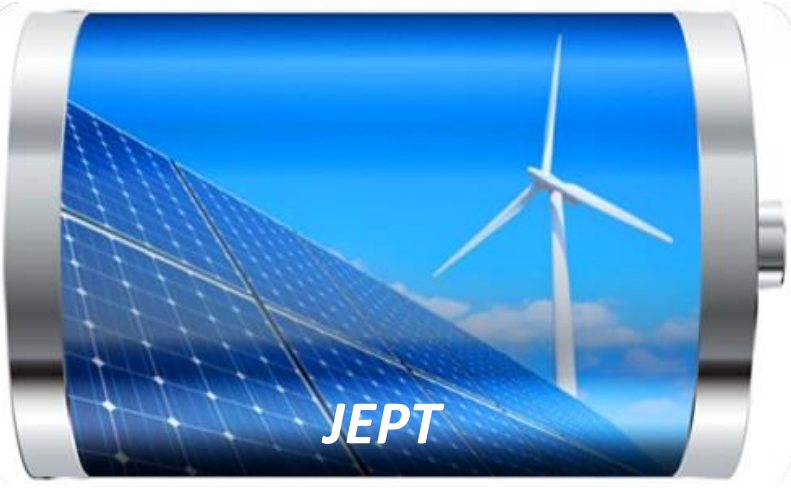

Enjoy JEPT by:

1. Submitting a manuscript

2. Joining in volunteer reviewer bank

3. Joining Editorial Board

4. Guest editing a special issue

For more details, please visit: http://www.lidsen.com/journal/jept 